\title{
Relações dialógicas na vida e na representação literária
}

\author{
Dialogical relations in life and in literary representation \\ Lucas Vinício de Carvalho Maciel \\ Universidade do Estado do Rio Grande do Norte - Mossoró - Rio Grande do Norte - Brasil
}

\begin{abstract}
Resumo: Os pensadores do Círculo de Bakhtin sempre sublinharam a relevância dos parceiros de interlocução e a importância do contexto real de comunicação (BAKHTIN/VOLOCHÍNOV, 2006). Seria de se esperar, assim, que exemplos de comunicação cotidiana fossem por eles valorizados. Contudo é notória nos textos do Círculo a preferência por exemplos literários. No presente artigo procura-se mostrar alguns motivos da literatura fornecer aos pensadores do Círculo exemplos de relações dialógicas dificilmente observáveis ou coletáveis em diálogos reais, como a representação dos diálogos interiores e as complexas interações dialógicas expressas nos romances polifônicos dostoievskianos (BAKHTIN, 2011). O diálogo interior, por razões tecnológicas, ainda hoje é inacessível, mas a literatura pode representá-lo. Já algumas das interações dialógicas representadas nos romances polifônicos até poderiam, em certa medida, serem apreendidas na realidade, porém isso implicaria acompanhar exaustivamente vários sujeitos, observando como as vozes próprias e alheias se combinam em diferentes contextos.
\end{abstract}

Palavras-chave: Relações dialógicas; Discurso literário; Discurso cotidiano

\begin{abstract}
The Bakhtin Circle thinkers emphasized the relevance of the interlocution partners and the importance of a real communication context (BAKHTIN/VOLOCHÍNOV, 2006). For that reason, it would be expected that they would appreciate the use of examples of an everyday communication. However, on their texts the literary examples are the majority. This article shows the reasons why the Circle thinkers elected literature to be the provider of dialogical relations examples, which are hardly observable or collectable in actual dialogues, like the representation of the internal dialogue and the complex dialogical interactions expressed on Dostoyevsky polyphonic novels (BAKHTIN, 2011). The internal dialogue, for technological reasons, is, still nowadays, inaccessible, but literature can build a representation of it. The dialogical interactions represented on the polyphonic novels could be apprehended in a real context, but it would be necessary to watch several subjects, observing how their own voices can be combined in different contexts.
\end{abstract}

Keywords: Dialogical relations; Literary discourse; Everyday discourse

\section{Introdução}

Muitas obras do Círculo de Bakhtin guardam entre si semelhanças, entre as quais se destacam a reincidente afirmação do caráter dialógico da comunicação humana e a marcante opção por ilustrar as discussões a respeito da linguagem verbal através de textos literários. Aliás, o discurso literário será empregado para ilustrar apontamentos, mesmo quando os interesses do Círculo não se restringem à palavra ou à literatura. Em Para uma filosofia do ato (2005-2006), por exemplo, Bakhtin empreende um ensaio de caráter amplo e filosófico a respeito da posição do homem na vida, mas ao final do texto opta por elucidar suas colocações através do exame de um discurso literário, de um poema.

Desse modo, ainda que se concordasse com propostas - como a de Todorov (2003), por exemplo - que pretendem "dividir" temporal e tematicamente as reflexões do Círculo, seria árduo localizar textos dos pensadores russos em que a questão das relações dialógicas, de um modo ou de outro, não está posta. Também é difícil divisar escritos do Círculo em que a literatura não apareça, ainda quando não desempenhe papel protagonista. 
Nas reflexões do Círculo há um constante movimento da literatura à vida, da vida à literatura, pois as relações dialógicas são de interesse fulcral para o pensamento bakhtiniano e a literatura é representação verbal que parece melhor expressar essas relações. Ao buscar uma disciplina que estudasse a linguagem além de sua materialidade estritamente linguística, Bakhtin e seus companheiros propuseram considerar a linguagem em sua situação social tanto ampla quanto imediata, situada no tempo e no espaço, uma linguagem, claro, intrinsecamente dependente das relações entre os interlocutores, entre o eu e o outro. Por essa proposta, aproximaram a linguagem da vida, ou melhor, aproximaram a reflexão linguística da linguagem na vida, inclusive da linguagem cotidiana e oral. Porém, por diversos motivos, amiúde optaram pelos exemplos literários em suas explanações. Alguns desses motivos podem ser apontados com maior grau de certeza, outros ficam restritos a conjecturas.

Entre as hipóteses, é de se imaginar que Bakhtin e seus companheiros liam (e viviam) a literatura de um modo bastante diverso daquele experimentado hoje. Hodiernamente a literatura tem papel fundamental na vida de muitas pessoas, especialmente aquelas mais escolarizadas. Todavia esse papel não é o mesmo nem para esses. No momento em que Bakhtin e seus companheiros viviam, a literatura não era apenas um requisito da erudição, era também, pelo menos para certos estratos sociais, algo de interesse enquanto entretenimento, em um mundo sem os convites multissemióticos de aparelhos eletrônicos como televisão e computadores.

A literatura era assim fonte de conhecimento e de diversão, possivelmente debatida e comentada em rodas informais de conversa. Falar de literatura era se integrar, e quanto mais se falava, mais se gostava, mais se lia, mais se voltava a comentar. Literatura era assunto rotineiro, bem diferente do cenário atual em que, salva alguma exceção, quem fala sobre literatura é geralmente um professor ou "erudito", em espaços escolares ou escolarizados, com propósitos práticos: "passar no vestibular", para mencionar o óbvio.

Portanto, quando se vê nas obras do Círculo inúmeras referências literárias, deve-se lembrar que isso resulta do momento cultural em que viviam Bakhtin e seus companheiros. Se vivessem hoje, seus exemplos seriam outros?

De todo modo, há algo próprio da representação literária que ajuda entender as razões dos exemplos do discurso literário serem empregados tão vastamente nas discussões do Círculo. Não se trata apenas de suposição, pois o próprio Bakhtin (2005-2006), já em um de seus primeiros textos, asseverava que o mundo da arte era o mais adequado para se chegar ao e entender o mundo real. A exposição a seguir pretende explicitar e justificar essa assunção bakhtiniana.

\section{Relações dialógicas: da vida à literatura, da literatura à vida}

Dos textos conhecidos do Círculo, possivelmente é em Para uma filosofia do ato (2005-2006), que Bakhtin expõe sua faceta mais filosófica e abrangente. Preocupado, entre outras questões, com a posição do homem na vida, Bakhtin não apenas se filia a vertentes filosóficas que tomam a vida em sua eventicidade e irrepetibilidade como também dá destaque à posição do homem, sempre definido em relação ao outro:

A vida conhece dois centros de valor que são fundamental e essencialmente diferentes, embora correlacionados um com o outro: eu e o outro; e é em torno desses centros que todos os momentos concretos do Ser se distribuem e se arranjam. (BAKHTIN, 2005-2006, p. 91).

O lugar do homem na vida está correlacionado com o lugar do outro. E essa relação entre o "eu" e o "outro" marcará toda reflexão desenvolvida por Bakhtin e seus companheiros. Ao estudar a linguagem, os pensadores do Círculo insistirão nas críticas tanto ao objetivismo abstrato quanto ao idealismo subjetivista (BAKHTIN/ VOLOCHÍNOV, 2006, por exemplo), seja porque essas correntes do pensamento linguísticos separam a linguagem do "eu", do sujeito falante, seja porque desconsideram que a linguagem só se efetua na relação, social e intersubjetiva, com o outro.

Por oposição a essas correntes, para os pensadores do Círculo, já desde Para uma filosofia do ato (2005-2006), a relação entre o homem e o outro está posta. Ao falar dessa relação, em que tem papel primordial a linguagem, Bakhtin poderia lançar mão de exemplos cotidianos, tão claramente marcados pelo caráter do irrepetível e situado. No entanto naquele momento histórico, sem a facilidade do auxílio de registros fônicos e de vídeo, transcrever um diálogo cotidiano não era fácil, e talvez resultasse algo artificial ou incompleto. Talvez por isso ou quiçá por seu profundo conhecimento (e interesse) literário, Bakhtin compara duas versões do poema "Separação" de Púchkin para esclarecer a questão do lugar único do eu e do outro na existência. Observa, por exemplo, a existência de dois centros axiológicos espaço-temporais nesse poema, em que o eu-lírico, na Rússia, sofre pelo regresso da mulher amada à Itália.

Analisando o poema, Bakhtin (2005-2006, p. 88) nota: "para ela [a Itália] é uma terra natal, para ele uma terra estrangeira; o fato de sua ida é para ela um retorno, enquanto para ele é uma partida [...]”. Essa orientação espacial diversa será expressa na linguagem, conforme assinala Bakhtin ao cotejar um trecho de duas versões do poema: 
"Rumando para as praias de uma distante terra estrangeira

Você estava partindo de sua pátria"

(Primeira versão, grifo nosso).

$\mathrm{e}$

"Com destino às praias de sua pátria distante Você estava partindo desta terra estrangeira" (Segunda versão, grifo nosso).

Na primeira versão, Itália é qualificada como "terra estrangeira", pois o centro de valor é o do eu-lírico, para ele a Itália é terra estrangeira. Já na segunda versão, "terra estrangeira" substitui Rússia, que era solo estrangeiro do ponto de vista da amada, italiana.

A linguagem literária serve, assim, de exemplo para a discussão a respeito dos centros de valores espaçotemporais; discussão essa que interessa a Bakhtin. Mas por que empregar trechos literários, e não outros, do cotidiano talvez? Não seriam mais adequados exemplos mais "reais"? Talvez. Porém quão difícil não seria naquelas circunstâncias históricas um banco de dados de textos orais e escritos cotidianos de onde se pudesse pinçar tal exemplo? Além disso, leitores assíduos de literatura, não espanta que os primeiros exemplos que ocorressem a Bakhtin e a seus companheiros fossem justamente os literários, que lhes ocupavam atenções teóricas e, possivelmente, ainda preenchiam horas de lazer. Contudo não apenas a facilidade de acesso e o vasto conhecimento literário explicam o porquê da recorrente opção por exemplos literários nos textos do Círculo.

\section{Relações dialógicas representadas no diálogo interior}

Há especificidades do discurso literário que ajudam a entender as razões da predileção dos pensadores do Círculo pelos exemplos literários. Uma pista pode ser encontrada na seguinte observação presente em Marxismo e filosofia da linguagem:

Como, na realidade, apreendemos o discurso de outrem? Como o receptor experimenta a enunciação de outrem na sua consciência, que se exprime por meio do discurso interior? Como é o discurso ativamente absorvido pela consciência e qual a influência que ele tem sobre a orientação das palavras que o receptor pronunciará em seguida? Encontramos justamente nas formas do discurso citado um documento objetivo que esclarece esse problema (BAKHTIN/VOLOCHÍNOV, 2006, p. 152).

Dessa observação, é interessante destacar dois pontos: a questão do discurso interior e o papel do discurso citado. A literatura é material propício para vislumbrar esses dois aspectos. Se o discurso interior é ainda hoje inacessível diretamente, uma vez que é impossível sondar exatamente o que alguém pensa ou diz consigo, há muito a literatura está repleta de descrições dos estados íntimos das personagens, expondo seus discursos interiores. Embora seja, claro, uma criação fictícia, o discurso interior representado em obras literárias tem seu interesse, na medida em que, de algum modo, simula as vozes que indubitavelmente habitam a consciência de qualquer pessoa.

Não por acaso, a representação do discurso interior será bastante comentada pelos estudiosos do Círculo, como se vê, por exemplo, nos exames que Bakhtin empreende em Problemas da poética de Dostoiévski (2011). O discurso interior de diversas personagens dostoievskianas merecerá algum comentário da parte de Bakhtin em sua análise da prosa do romancista russo. Desde as primeiras personagens, como Makar Diévuchkin, de Gente Pobre, e Goliádkin, de $O$ duplo, até os heróis dos grandes romances, como Raskólnikov, de Crime e castigo, o príncipe Míchkin, de O idiota, Aliócha e Ivan, de Os irmãos Karamázov, todos, de um modo ou outro, terão seus discursos interiores apreciados por Bakhtin.

Da obra dostoievskiana, contudo, provavelmente é o romance Memórias do subsolo (2008a) o mais favorável à contemplação do discurso interior. Por se aproximar a um monólogo, a obra dá ensejo à observação do homem dialogando com as vozes no interior de sua autoconsciência. Tem-se acesso pela via da literatura, então, a algo inacessível na realidade: à consciência de um sujeito, em que vozes suas e alheias se confrontam. É cabível admitir que qualquer ser humano tem sua consciência habitada por inúmeras vozes que ouviu e ouve ao longo de sua vida. Como, porém, ter acesso a esse diálogo? Essa impossibilidade é superada pela literatura, que, sendo fictícia, propicia nesse caso uma representação relativamente adequada da realidade.

Segundo Bakhtin (2011, p. 263), na "confissão do 'homem do subsolo', o que nos impressiona acima de tudo é a dialogação interior extrema e patente", pois seu microdiálogo é habitado por vozes alheias escutadas ou até mesmo inventadas pela personagem.

$\mathrm{Na}$ passagem a seguir, por exemplo, o homem do subsolo simula um debate com seus opositores:

\footnotetext{
'Não é possível', vão gritar-vos, 'não podereis rebelarvos: isto significa que dois e dois são quatro! A natureza não voz pede licença; ela não tem nada a ver com os vossos desejos nem com o fato de que as suas leis vos agradem ou não. Deveis aceitá-la tal como ela é e, consequentemente, também todos os seus resultados. Um muro é realmente um muro... etc. etc.' Meu Deus, que tenho eu com as leis da natureza e com a aritmética, se, por algum motivo, não me agradam
} 
essas leis e os dois e dois são quatro? Está claro que não romperei esse muro com a testa, se realmente não tiver forças para fazê-lo, mas não me conformarei com ele unicamente pelo fato de ter pela frente um muro de pedra e de terem sido insuficientes as minhas forças. (DOSTOIÉVSKI, 2008a, p. 25).

O recurso às aspas, por isolar a palavra supostamente alheia, ajuda a divisar as relações dialógicas que se dão entre a voz do homem do subsolo e a voz por ele refutada. Opondo-se a um discurso racionalista - dois e dois são quatro -, a personagem mostra o seu posicionamento, o seu pensamento, a sua voz. Se é impossível o acesso às vozes que habitam a consciência do homem, mais difícil ainda é separar em sua atividade cognitiva o que seria, supostamente, seu daquilo que pertenceria ao outro. Porém, em representações literárias como essa, pode-se observar o confronto entre a voz alheia e a voz própria nos limites do discurso interior, no âmbito da autoconsciência.

Tais diálogos interiores podem justamente atender aos questionamentos de Bakhtin/Volochínov (2011, p. 125), quando se perguntam como "apreendemos o discurso de outrem? Como o receptor experimenta a enunciação de outrem na sua consciência, que se exprime por meio do discurso interior?". Na impossibilidade de acesso à consciência dos sujeitos, a literatura fornecerá protótipos para investigação dessas questões. A literatura, assim, é um palco adequado para a representação das relações dialógicas que se dão no interior das consciências, para simular as relações entre a palavra própria e a palavra outra no âmbito do discurso interior.

Essa dádiva da literatura provavelmente é uma das razões a explicar a notória preferência dos estudiosos do Círculo pelos exemplos literários. Além desse motivo, outros podem ser elencados.

\section{Relações dialógicas representadas no diálogo exterior}

$\mathrm{Na}$ vida, os homens interagem constantemente em diálogos imediatos, na presença física de seus interlocutores, com os quais compartilham contextualmente o mesmo espaço e tempo. Por sua simplicidade e pela comumente explícita alternância de turnos, o "diálogo real" será apontado por Bakhtin (2003, p. 275) como a "forma clássica de comunicação discursiva". A propósito, por seu vínculo imperativo com a situação imediata de interação, o diálogo representaria também um dos mais - talvez o mais - evidentes exemplos de gêneros primários (BAKHTIN, 2003).

Além desses, claro, o homem também faz uso dos gêneros secundários (BAKHTIN, 2003), aqueles cujo entendimento não depende tão fortemente do contexto imediato de enunciação. Um livro, por exemplo, escrito na
Grécia há séculos, pode ser compreendido hoje no Brasil. Mesmo que, ao viajar por espaços e tempos diversos, a compreensão do enunciado não seja tão completa ou perfeita, certamente é mais possível recuperar seu sentido do que o de uma conversa da qual não se tem registro algum.

De todo modo, seja, por exemplo, em diálogos do dia a dia ou através de complexas obras científicas, os homens sempre estão retomando palavras anteriores, de outros ou próprias, às vezes preocupados em destacar as palavras como alheias, às vezes até mesmo esquecidos de que qualquer enunciação sempre é mosaico de vozes anteriores. Em qualquer interação verbal há sempre relações dialógicas, há vozes sendo retomadas e as palavras enunciadas poderão também, por sua vez, virem a se (re)verbalizadas em enunciados vindouros.

Diante da profusão de relações dialógicas presentes na vida, em face dos inúmeros diálogos cotidianos, por que o interesse em estudá-los nas representações literárias? Há dois motivos, pelo menos. Um, já destacado, é facilidade de encontrar na literatura senão registros, pelo menos simulacros, de diálogos. Naquele momento histórico em que viviam Bakhtin e seus companheiros, gravar e/ou transcrever diálogos não era tarefa fácil, dados os impedimentos tecnológicos e, é de se supor, certa inconveniência em registrar certos diálogos, tendo em vista o tenso momento político da Rússia da primeira metade do século XX.

Um segundo motivo é singular ao discurso literário: a possibilidade de "representação" de vozes em diálogos. Em um tratado científico, pode haver várias vozes, vários estudiosos podem ter suas palavras citadas, mas a interação entre eles é sempre mediada pelo autor que organiza essas vozes. Se o autor X, por exemplo, cita em seu trabalho os filósofos A e B, estes não estarão em interação direta, pois suas palavras estarão sempre envoltas pelo discurso de X, que organiza, dá espaço, concorda com ou discorda das palavras citadas. Na representação literária, o narrador também é uma espécie de organizador das vozes, mas pode haver um confronto direto da personagem $\mathrm{D}$ com a personagem $\mathrm{F}$.

As relações dialógicas nas representações literárias podem se dar entre personagens. Em Problemas da poética de Dostoiévski (2011), Bakhtin pontua que um dos modos de representação das interações verbais entre as personagens é o "diálogo exterior composicionalmente expresso", quando se representa a troca de turnos entre personagens, falando em discurso direto. Um exemplo do procedimento é a passagem a seguir, reproduzida a partir de Bakhtin (2011, p. 296-297, grifo do autor). No trecho do romance Os irmãos Karamázov de Dostoiévski, os irmãos Aliócha e Ivan conversam sobre o possível assassino do pai deles: 
- Só uma coisa eu sei - pronunciou Aliócha do mesmo modo quase sussurrando. - Quem matou nosso pai não foste tu.

- "Não foste tu"! Que não foste tu é esse? - Ivan estava petrificado.

- Não foste tu que matou nosso pai, não foste tu! repetiu Aliócha com firmeza.

Fez-se uma pausa de meio minuto.

- Ora, eu mesmo sei que não fui eu, está delirando? pronunciou Ivan com um riso pálido e contraído. Tinha o olhar como que cravado em Aliócha. Mais uma vez estavam parados diante do lampião.

- Não, Ivan, tu mesmo disseste várias vezes a ti mesmo que era o assassino.

- Quando foi que eu disse?... Eu estava em Moscou... Quando foi que eu disse? - balbuciou Ivan totalmente desconcertado.

- Tu disseste isto a ti mesmo muitas vezes quando ficaste só nesses dois terríveis meses - continuou Aliócha com voz baixa e nítida. Mas já falava como tomado de extrema excitação, como movido não por sua vontade, obedecendo a alguma ordem indefinida. - Tu te acusavas e confessavas a ti mesmo que o assassino não era outro senão tu. Mas quem matou não foste tu, estás enganado, não és tu o assassino, ouve-me, não és tu! Foi Deus quem me enviou para te dizer isso.

Ivan e Aliócha conversam, o que é representado por um diálogo exterior composicionalmente expresso. É exterior no sentido de que suas palavras são verbalizadas na interação com o outro; não são palavras que permaneçam no interior da consciência de cada personagem. É composicionalmente expresso, pois está representado em discurso direto, simulando as supostas vozes diretas das personagens, aquilo que "de fato" teriam falado. Essas falas diretas ocupam um lugar composicional e vêm expressas em discurso direto e não, por exemplo, sumarizadas ou reportadas em discurso indireto pela voz do narrador.

\section{Relações dialógicas representadas: algumas singularidades da prosa dostoievskiana}

Os diálogos em Dostoiévski, porém, não apenas simulam conversas cotidianas. Segundo Bakhtin (2011, p. 281), Aliócha é portador de um "discurso penetrante", um discurso que atinge as palavras interiores do outro. Aliócha expõe em sua voz aquilo que o irmão procura ocultar de si mesmo, a culpa que atribui a si. Por esse dom, a personagem dostoievskiana dialoga com a voz interior do outro e ao expô-la no diálogo corrente acaba por integrar "diálogo interior" e "diálogo exterior".

Através desse recurso literário, Dostoiévski torna possível vislumbrar dois pontos de interesse para o estudo das relações dialógicas: o diálogo direto e o acesso a vozes interiores. Se o estudo do diálogo exterior será facilitado com os avanços tecnológicos, estes mesmos avanços não permitem (ainda) um acesso às vozes interiores. Há apenas o relato, nem sempre confiável e certamente nunca isento, de quem se dispõe a falar sobre seus pensamentos, seus sentimentos, suas vozes interiores.

Por isso mesmo, a representação literária traz possibilidades e facilidades para o estudo das relações dialógicas. No caso específico de alguns romances de Dostoiévski, Bakhtin (2011) irá ainda além, asseverando existirem diversos procedimentos formais e temáticos dos quais resulta o "grande diálogo do romance". Entre esses procedimentos está a passagem de uma mesma afirmação "por diferentes vozes que se opõem umas às outras" (BAKHTIN, 2011, p. 298).

Prosseguir com o exemplo de Os irmãos Karamázov pode elucidar essa concepção bakhtiniana.

No trecho anterior, observa-se ser refutada por Aliócha a voz interior de Ivan que o condena pelo assassinato de seu pai. Aliócha afirma categoricamente "não foste tu". Há, assim, a passagem de uma mesma afirmação por diferentes vozes, que têm orientações diferentes, pois a colocação de Aliócha rebate a acusação que Ivan se faz. A voz de Ivan é retomada por Aliócha, que modifica sua orientação e entonação. Se na voz de Ivan há acusação, na de Aliócha há perdão.

Esse diálogo, porém, não estará encerrado, pois mesmo sob o matiz da absolvição de Aliócha, Ivan ainda continua a se martirizar, até mesmo porque no diálogo interno de Ivan ecoa também a voz de Smierdiakóv, outra personagem que o acusa, senão do assassinato, pelo menos, da cumplicidade e, até mesmo, de influência e instigação para tal ato.

Smierdiakóv, o real assassino, em sua última conversa com Ivan, retoma algumas das palavras ditas por este em outras oportunidades:

Antes eu alimentava a ideia de começar uma nova vida com esse dinheiro, em Moscou ou, melhor ainda, no exterior, eu acalentava esse sonho, ainda mais porque "tudo é permitido". Isso o senhor me ensinou de verdade, porque naquela época o senhor me dizia muitas coisas como essa: pois se Deus definitivamente não existe, então não existe nenhuma virtude, e neste caso ela é totalmente desnecessária. Isso o senhor realmente me disse. E foi assim que julguei. (DOSTOIÉVSKI, 2008b, p. 816).

Smierdiakóv se refere ao dinheiro por ele roubado de Fiódor Karámazov e acusa Ivan de tê-lo feito acreditar que "tudo é permitido", que "Deus definitivamente não existe, então não existe virtude nenhuma". Ao ouvir da boca de Ivan que tudo é permitido, Smierdiakóv acredita que 
aquele o incita para o crime: o crime seria permito, pois tudo é permitido, não há virtude. Segundo Smierdiakóv, a justificativa para seu crime, para o assassinato de Fiódor, foram os "ensinamentos" de Ivan e por isso este também se sente culpado pelo assassinato do pai.

Compõem-se, dessa maneira, um emaranhado jogo de relações dialógicas, há relações entre microdiálogo, diálogo composicionalmente expresso e grande diálogo: há a passagem de uma voz por várias e diferentes bocas.

As palavras que ecoam no microdiálogo de Ivan, que disse a si "mesmo muitas vezes" quando ficara só que era o assassino, aparecem nos diálogos composicionalmente expressos da personagem com Aliócha e com Smierdiakóv. A questão do reconhecimento da culpa, a assunção de que (não) "foste tu”, passa pela voz de várias personagens: de Ivan, de Aliócha, de Smierdiakóv. Ivan se (auto)condena, Aliócha o absolve, Smierdiakóv o incrimina.

Esse debate, vale notar, não terminará, pois Ivan cai em uma espécie de loucura ou delírio, sem conseguir se reconhecer culpado ou se assumir inocente. Desse modo, permanece inconclusa uma questão importantíssima para o "grande diálogo do romance", a questão de ser "tudo permitido", questão essa relacionada à existência ou não de Deus.

Se nos limites deste artigo são citadas apenas duas passagens, é importante lembrar que no longo romance - cerca de 1000 páginas na edição brasileira consultada - essas questões serão debatidas várias vezes pelas personagens em diferentes arranjos dos atores envolvidos - ora algumas personagens, ora outras -, em espaços e tempos diversos, permitindo que as ideias passem por várias bocas, sejam contempladas de perspectivas diversas, adentrem as consciências de diferentes personagens, podendo retornar aos diálogos.

Embora também no mundo real seja possível contemplar tal debate de ideias, seria bastante difícil acompanhar o diálogo de vários sujeitos em interação com vários outros, e não necessariamente os mesmos, a fim de observar quando certos assuntos são retomados, debatidos, reelaborados. Isso sem contar com a impossibilidade de acesso à consciência dos sujeitos envolvidos.

Assim, se a literatura não é a realidade, nesse caso através da obra literária obtém-se uma simulação das interações verbais humanas, tão caras a Bakhtin, empenhado não apenas no esclarecimento da poética de Dostoiévski, mas também na investigação das relações dialógicas que constituem a comunicação humana.

Os romances do autor russo, aliás, justamente por seu caráter literário e fictício trarão outros processos interessantes para o estudo das relações dialógicas. Nas obras dostoievskianas são frequentemente colocadas em foco situações limites: o sonho, a loucura, o encontro de sujeitos opostos. Segundo Bakhtin (2011), são estratégias composicionais de Dostoiévski a fim de reunir no mesmo plano ideias e temas dispersos na realidade e que talvez dificilmente se choquem frontalmente no mundo real.

Mesmo sendo um realista, Dostoiévski não se prende à verossimilhança, se o objetivo é dar ensejo ao debate de vozes, ao diálogo de ideias. Em Uma criatura dócil, por exemplo, Dostoiévski recorre a um "estenógrafo", que pudesse anotar todos os confusos pensamentos de um marido, cuja esposa acabara de se suicidar. Por esse artifício, Dostoiévski divisa as vozes, tanto próprias quanto alheias, que habitam a consciência atormentada do homem. Para vislumbrar tal embate de vozes, o "realista" Dostoiévski não se furtou a empregar um procedimento quase fantástico.

Em Bobok, Dostoiévski descreve os diálogos de mortos, que, estando enterrados e já em diferentes estados de decomposição, podem falar mais livremente, sem as amarras da cordialidade e da falsidade mundana. Tratase, no dizer de Bakhtin (2011), de "diálogos no limiar", diálogos em situações limites, quando o homem se vê convidado a expor sua condição, seus pensamentos mais íntimos, sua voz mais humana.

Todavia também em condições mais verossímeis, mais ainda assim por vezes surpreendentes, os homens e suas ideias são confrontados. Em $O$ idiota, por exemplo, Dostoiévski reúne o ingênuo príncipe Míchkin e o voluptuoso Rogójin ou o religioso Aliócha e seu irmão ateu Ivan, em Os irmãos Karamázov.

Segundo Bakhtin (2011, p. 168-169, grifo do autor):

Em Dostoiévski, os participantes da ação se encontram no limiar (no limiar da vida e da morte, da mentira e da verdade, da razão e da loucura). E aqui são apresentados como vozes que ecoam, que se manifestam 'diante da Terra e do céu'.

Para conseguir essa interação no limiar, Dostoiévski não poupou esforços, nem mesmo quando preciso abdicar de certa pretensa verossimilhança, cara a autores realistas mais radicais. Ao colocar em jogo várias personagens, com suas vozes e ideias, Dostoiévski representa diálogos nem sempre verossímeis, mas sempre interessantes do ponto de vista das interações dialógicas. Daí porque, para Bakhtin (2011, p. 300), Dostoiévski tenha alcançado o auge da maestria da "ciência do diálogo".

Também esses encontros surreais ou pouco críveis, possíveis na representação literária, ajudam a entender a preferência de Bakhtin pelas obras literárias na exemplificação das relações dialógicas. Pelo ficcional é concebível conjugar vozes dispersas na realidade, sujeitos de diferentes estratos sociais, de diversos caráteres, de distintos posicionamentos, confrontados no limiar, incitados a expor o que há de mais humano em sua essência. 
As relações dialógicas são um fenômeno onipresente nas interações verbais cotidianas, porém a literatura, por seu caráter ficcional - mas ao mesmo tempo tão humano -, permite ver e entrever exemplos dificilmente coletáveis em enunciados "reais".

\section{Algumas considerações finais}

As reflexões do Círculo têm sido empregadas para propor e justificar o estudo e o ensino de discursos não literários. Especialmente a partir do ensaio Os gêneros do discurso (BAKHTIN, 2003), vários linguistas e educadores têm sublinhado a importância de se olhar para outras práticas discursivas, para além apenas de gêneros literários ou estritamente escolares, como aqueles designados genericamente como "redação". As perspectivas bakhtinianas ganharam ainda mais força na medida em que acabaram por ecoar em documentos oficiais de regularização do ensino, como, para citar o exemplo mais evidente, os Parâmetros Curriculares (BRASIL, 1998) que versam sobre o ensino de língua portuguesa.

Um dos impactos das concepções bakhtinianas para o campo dos estudos linguísticos bem como para o ensino de língua vem sendo o alargamento dos objetos de estudo, na medida em que se contemplam agora vários gêneros anteriormente pouco examinados. Ilustra essa nova prática o crescente número de estudos sobre gêneros como "reportagem", "editorial", "charges", etc., que não apenas ocupam vários pesquisadores do campo da linguagem como também ganham espaço nos materiais didáticos.

De algum modo, pode parecer que esses gêneros estão bastante vinculados à vida, talvez até mais do que a literatura. Se anteriormente a literatura era onipresente no ensino de língua, figurando uma sonhada escrita literária (ou literarizada) como objetivo a ser atingido, hoje muitos gêneros de caráter literário perdem espaço para gêneros supostamente mais vinculados ao imediato real, a exemplo dos citados anteriormente: notícia, reportagem, charges. Esses gêneros, partícipes "legítimos" da realidade, trazem relações dialógicas interessantes, porque, muitas vezes, expõem falas de pessoas reais - ainda que de forma caricatural, no caso da charge. Essas práticas discursivas mostram relações dialógicas da ou mais próximas à realidade, diferentemente da literatura, que, geralmente de caráter fictício, já impõe um distanciamento do discurso "real".

Todavia, como se procurou mostrar neste artigo, a literatura apresenta possibilidades de vislumbrar relações dialógicas inacessíveis ou dificilmente acessíveis na realidade. Mesmo ficcional, a literatura é produto humano e representa o humano. Conforme reconhece o "homem do subsolo", ele mesmo "inventa" as palavras com as quais dialoga. Mas essas palavras são inventadas, a partir da realidade, pois passou anos "ouvindo por uma fresta estas vossas palavras" (DOSTOIÉVSKI, 2008a, p. 52).

Que a literatura seja "inventada" não é demérito. No que toca às relações dialógicas, a literatura fornece exemplos como o do "microdiálogo", o diálogo no interior da consciência, que seria impossível de se observar na realidade. Também no que se refere ao arranjo polifônico, em que diversas vozes transitam por várias bocas, personagens, consciências e contextos, qual não seria a dificuldade de acompanhar tal debate de ideias no plano real?

Para retomar uma questão colocada inicialmente, pode-se questionar se Bakhtin e seus companheiros ainda se dedicariam aos exemplos literários na análise das relações dialógicas, dados: (i) os avanços tecnológicos que permitem, por exemplo, o registro de diálogos cotidianos e (ii) as novas formas de representação, em geral multimodais, que ganham espaço frente à literatura, considerada, muitas vezes, ultrapassada.

Difícil é fazer tal conjectura, mas vale notar que, a despeito dos avanços tecnológicos, ainda não se tem acesso à consciência dos homens, motivo pelo qual a representação literária do microdiálogo continua sendo de interesse. Se hoje o diálogo exterior pode ser gravado, registrado, filmado, o diálogo interior ainda pode ser apenas simulado.

Além disso, por meio de recursos multimodais, podem-se representar várias relações dialógicas, como ilustram as interações, reais ou fictícias, entre sujeitos ou personagens expostos em vídeos, telenovelas, filmes. Ainda assim, seria bastante difícil transmitir para as telas da TV, do cinema, do computador, toda a complexa rede de relações dialógicas que se desenha em um romance como Os irmãos Karamázov. Desse modo, permanece bastante intrínseca à literatura a representação de certas relações dialógicas.

Não se trata de exaltar mais uma vez a literatura, mas de buscar entender os motivos pelos quais Bakhtin e seus companheiros tantas vezes optaram por exemplos literários. As relações dialógicas são fenômeno inerente à comunicação humana, presente em qualquer enunciado cotidiano. A literatura, contudo, continua fornecendo exemplos singulares dessas relações.

\section{Referências}

BAKHTIN, Mikhail. Para uma filosofia do ato. Tradução não revisada, para fins didáticos e acadêmicos, realizada por Carlos Alberto Faraco e Cristovam Tezza. [S.I.: s.n.], [entre 2005 e 2006].

BAKHTIN, Mikhail. Problemas da poética de Dostoiévski. Trad. Paulo Bezerra. Rio de Janeiro: Forense Universitária, 2011. 
BAKHTIN, Mikhail. Os gêneros do discurso. Estética da criação verbal. Tradução Paulo Bezerra. São Paulo: Martins Fontes, 2003, p. 261-306.

BAKHTIN, Mikhail. Marxismo e filosofia da linguagem. Tradução Michel Lahud \& Yara Frateschi Vieira. São Paulo: Hucitec, 2006.

BRASIL. Ministério da Educação. Parâmetros curriculares nacionais: terceiro e quarto ciclos do ensino fundamental: língua portuguesa. Brasília: MEC/SEF, 1998.

DOSTOIÉVSKI, Fiódor. Memórias do subsolo. Tradução, notas e prefácio de Boris Schnaiderman. São Paulo: Editora 34, 2008a.
DOSTOIÉVSKI, Fiódor.. Os irmãos Karamázov. Tradução, prefácio e notas de Paulo Bezerra. São Paulo: Editora 34, 2008b.

TODOROV, Tzvetan. Prefácio à edição francesa de Estética da criação verbal. Tradução do prefácio por Maria Ermantina de Almeida Padro Galvão. In: BAKHTIN, Mikhail. Estética da criação verbal. Trad. Paulo Bezerra. São Paulo: Martins Fontes, 2003, p. xii-xxxiv.

Recebido: 05 de fevereiro de 2015

Aprovado: 14 de agosto de 2015

Contato: lucasvcmaciel@yahoo.com.br 